\title{
Jolly phonics: effective strategy for enhancing children english literacy
}

\author{
Ni Putu Pebri Ariati, Ni Nyoman Padmadewi, and I Wayan Suarnajaya \\ English Education Department, Ganesha University of Education, Singaraja Bali Indonesia.
}

\begin{abstract}
Having strong foundation in English literacy nowadays is believed to be a very crucial requirement for the children to survive and success both in educational and social lives. One of the most effective strategies for enhancing children's early reading and literacy skill is through Jolly Phonics. Despite the popularity and its effectiveness, there is still factor to the absence of the strategy, namely lack of teacher knowledge. This paper is intended to share the techniques of how to implement Jolly Phonics strategy for teaching and developing children's English literacy. This study was conducted in one of innovative bilingual schools in Denpasar, Bali. The study employed descriptive qualitative method as a research design and used observation, documentation and interview to collect the data from the teacher. The findings showed that the teacher had successfully implement the 5 skills in Jolly Phonics, namely (1) learning the letter sounds, (2) learning letter formation, (3) blendingfor reading, (4) identifying sounds in words-for writing and (5) tricky words, through variety of enjoyable techniques involving children's sight, sound and kinesthetic means. Thus, implementing Jolly Phonics through techniques explained will improve children's overall English literacy skill.
\end{abstract}

Keywords: Jolly Phonics, English literacy

\section{Introduction}

The term literacy has become a very crucial terms in education during the last few decades. As states by Roskos, Christie \& Richgels, extensive research in the field of literacy, particularly research on literacy development of young children has been conducted and becoming a basis for everyday practice [5]. This is because having a strong foundation in literacy, specifically English literacy is very beneficial for the continuity of children's life, as today English is used as lingua franca and international language of communications.

The fact that having strong literacy foundation is fundamental for children is supported by Alberta Education, who claims that literacy has always been a basis of learning [4]. Moreover, Morrow also states that children's futures are partly determined by how well the children are guided to literacy [9]. Regarding to the urgency of literacy, the children therefore should be guided to literacy right from the very early age. The earlier they get into literacy, the more experiences they will gain to survive both in educational and social lives. 
However, finding an appropriate yet innovative strategy to develop and enhance children's Engish literacy is not an easy thing to be done. Udosen \& Ukpak (in Ekpo et al) states that most pupils in preschool come without a slight reading readiness [3], and they have no idea of how to sound out the letters in English. Consequently, Mullins points out that many children struggle to decode words [2]. In this case, one of the most effective strategies that could be used to enhance children's early reading and literacy skill is Jolly Phonics.

Jolly Phonics is a fun- systematic program designed for young or beginner learner to develop their reading and literacy skill. According to Lloyd, Jolly Phonics teaches the 5 main skills, where the children are firstly taught the 42 sounds in English, and then continued into blending and reading skill, at the same time they are taught to write by identifying the sounds in words [13]. In addition, Farokhbakht \& Nejadansari also state that Jolly Phonics incorporates multisensory approach, where the information is delivered through sight, sound and kinesthetic means [6], which is really suitable for young children's characteristics.

Dixon et al, as well as Farokhbakht \& Nejadansari have conducted a study to see the effectiveness of Jolly Phonics in improving the children's early English literacy. The findings of both study shows that children who are taught by using Jolly Phonics has better performance on reading, spelling and literacy compared to those who are conventionally taught $[12,6]$. Other study conducted by Ruhaena has also proved that Jolly phonics implementation affects not only the children's English literacy ability, but also their Indonesian literacy [7]. As a result, Ogbemudia \& Alasa claims that Jolly Phonics instructional strategy is a very effective panacea to reading difficulty faced by children [10].

Despite the popularity and its effectiveness, there are still factors to the absence of the strategy. In this case, Mullins have listed few factors to the absence of Jolly Phonics at school, such as lack of materials and lack of teacher knowledge [2]. For that reason, this study was carried out to assist teachers on how to develop and enhance children's English literacy skill through Jolly Phonics strategy. In addition, the problem in this study were directed to answer questions about thet kinds of technique used for implementing Jolly Phonics and how those techniques implemented in the classroom.

The remaining sections of this paper will discuss about method of study, findings and discussion of jolly phonics implementation in the classroom, which are ended with closure. Therefore, this paper is expected to be able to inspire other teachers on how to develop and enhance children's early English literacy through Jolly Phonics strategy.

\section{Methods}

This study was a descriptive qualitative study which was conducted at Dyatmika Kindergarten, Denpasar Bali Indonesia. The subject of this study was a qualified and experienced native teacher who taught Jolly Phonics at Dyatmika Kindergarten. She graduated from one of university in Australia and had been been teaching children through Jolly Phonics for about 3 years. The data were collected through a series of observation and documentation in Dyatmika kindergarten class, and at the same time through interview with the teacher, which was then analyzed descriptively.

\section{Results and Discussion}

Jolly Phonics at Dyatmika Kindergarten was implemented following the principles of effective literacy instructions states by Roskos, Christie \& Richgels, in which the teacher 
had succesfully engage in a rich conversation with children through story reading, shared reading activities, and etc [5]. As have been stated, English literacy has become the core important of all learning, because nowadays English is used as a universal language to explain most knowledge and technology. It is not only used for the sake of schooling but the children can use it for life. Realizing the fact stated, Dyatmika Kindergarten then used Jolly Phonics to help the children master the English literacy skill. In this case, the skills in Jolly Phonics are attractively taught and creatively developed by the teachers based on children's need and situation, so children could easily engage with it. It was also taught and introduced systematically following the letters groups and skills sugessted, starting from the easiest to the complex one. However, the findings of this study was not in the line with Lloyd, where it was suggessted to introduce 1 sound per day [13]. Here, the teacher adapted the program into longer one, due to the children's multicultural language background, so the section for the sounds introduction were maximized by introducing only 1-3 sounds per week. This action was in accordance with Ehri, et al and Boyadzhyan who propose that phonics should be systematically taught as a part of literacy program and, it should be adapted based on children's ability $[8,1]$. Therefore, the following are the techniques used by the teacher for teaching English literacy through the five skills in Jolly Phonics.

\subsection{Learning the Letter Sound}

Knowledge of letter sounds was the first skill needed to be mastered by children in learning English literacy through Jolly Phonics. Actually, the 42 sounds in English were divided into 7 groups of letters, where in a group consisted of 6 letters, such as $s, a t, i, p, n$ and so forth. Based on the findings, the teacher introduced 1-3 sounds in a week, and it would always be reviewed and reinforced. There were some techniques used for teaching letter sound skill to children, namely story reading, song and action as well as games, as can be seen below.

a) Story Reading

Story reading was done everyday for the children either as introductory activity or main activity for learning letter sound. The story read for the children could be any story, story with rhyming or storyline from Jolly Phonics book itself. Through story reading the children was not only able to enjoy the story read by the teacher, but also listen to the words and sounds in English as well as develop their comprehension skill and critical thinking.

b) Song \& Action

The second one was song and action, where the children were asked to sing the Jolly Phonics song, at the same time they did the action for the sound. For instance, the sound $/ s /$ represented by snake and the children needed to sing and weave their hand in an 's' shape like a snake and say ssssss. And as a follow up acivity, the teacher asked them to find words or things in the classroom which was started with $/ s$ / sound, like sun, ship, starfish, etc.

c) Games

The teacher provided Jolly Phonics games, which were software games to be played through computer by the children. Here, the games designed interactively where the children could practice all the five skills of Jolly Phonics independently. For instance, they could learn as they played with the letter sound and the picture represented by the sound, such as 'i' for 'inky' the mouse, 's' for 'snake', etc. Thus, with a clear instruction provided by the game that could guide them through the activities, they would be able to train their self-independency and determine what to learn and what to play.

\subsection{Learning Letter Formation}

When children knew the letter sound, at the same time they needed to know the letter formation. Firstly, teacher showed the letter example through song or flashcard and wrote it 
on the board. After that, the teacher showed the letter formation in the air as she gave instruction to be followed by children. For instance, in the letter $/ 1 /$, the teacher said 'start at the top, down and cross' and it should be noted that teacher needed to do the formation in a mirroring position, so children could immitate it correctly. And as a follow up activity, the teacher provided a kind of sound sheet, consisted of picture represented the letter sound, space for the children to trace and do the letter formation, as well as some pictures where children needed to determine which picture started with the letter sound being practiced. At the end, they were asked to circle the best letter they formed to boost their confidence.

\subsection{Blending - For Reading}

Blending can be started when the first six letter sounds have been taught by teacher. The skill needed to be frequently practiced by looking at the letters, saying the sound and hearing the words. In this case, teacher firstly planned lists of words needed to be blended by children, so it would be easier in teaching it. Flashcard was the main media used by the teacher, where at the first time teacher always did a kind of review through the letter sound. Variety of techniques was employed, such as having children in a small group and giving one flashcard for each of them to be blended. This was done in order to make them took responsibility toward themselves firstly, and when they found any obstacles in blending the word, the teacher would fix it together with the group. Another way used by teacher was having small whiteboard and some single letter flashcards, as can be seen below.

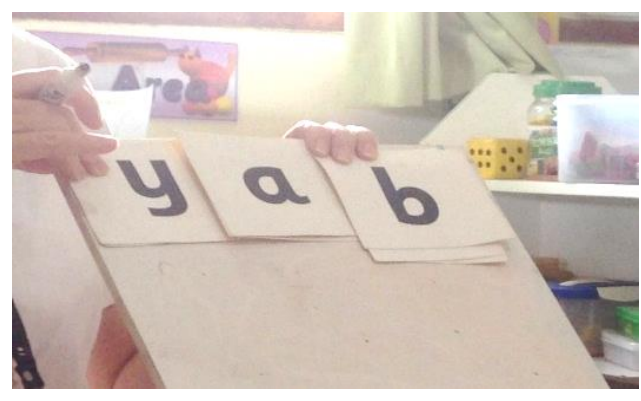

Pict. 1. Whiteboard Blend

Picture 1 above shows the example of whiteboard blend with CVC word. The example of word ' $y a b$ ' above actually has no meaning, but when the children knew most of letter sounds they would be able to blend the word correctly. The teacher put 1 by 1 letter to be sounded out and then blended by the children. This technique was found attractive, because it was taught slowly but sure, and required the children to look at the letter, sound out the letter 1 by 1 , and hear the word before they finally could say the word. As a follow up activity, the teacher run a home reading program, where the children needed to practice their blending and reading skill at home with their parents and noted their progress in their reading records. Actually, those program was in the line with techniques of of promoting autonomous learning proposed by Padmadewi where providing lots of book and facilitate children's early reading skills through reading log or reading records could motivate and lead them to be an autonomous learners, which was very beneficial not only in present, but also future life [11].

\subsection{Identifying Sounds in Words - For Writing}

In learning to write, the children were required to have phonological awareness, where they could listen for the spoken words, identify, and write the sound in that word. There were variety of techniques used by the teacher, starting from copying, modeling, in which the 
teacher could slowly rub the words written on the board and asked them to try to write on their own. And finally, gave chance for the children to write independently, either through news writing, story writing, or free writing as can be seen below.

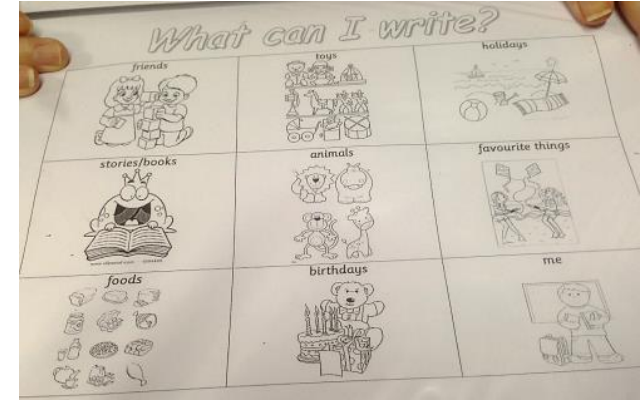

Pict. 2. Free Writing Guide

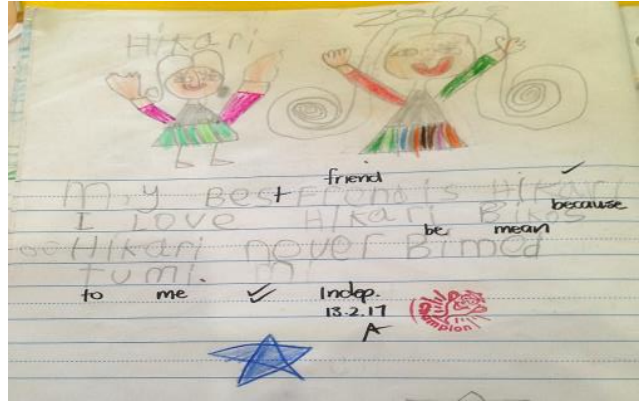

Pict. 3. Free Writing Example: Friends

Picture 2 above shows the guide for children's free writing. In free writing, they could write about friends, toys, food etc. Here, teacher always provided alpabeth and words for writing, like $a$, and, an, brother, etc, just in case they forgot how to write it because those words were a kind of tricky words. Picture 3 is the example of one child's writing, where she tried so hard to write about her friend independently. Firstly, the teacher let the children drew while thinking about what they needed to write. When she finished drawing, she started writing by hearing the sounds in words. Based on the example above, it could be said that this child was in the preparation step to become independent writer. She put the message she wanted to say into her writing, which could be understood by others. She knew why she loved her friend and stated the reason clearly. She only needed to try to hear sounds in words more carefully, and remember some more tricky words, like friend, to, me, etc. By doing this activity frequently, the children would be used to writing and ready to be independent writer.

\subsection{Tricky Words}

Tricky words can be defined as irregular words which are difficult to spell, but frequently happened in many text. The study found that the teacher introduced 2-3 new tricky words per week for the children through variety of techniques, such as flashcard activity where teacher introduced tricky words through flashcards, and they needed to create sentence with the tricky word stated. For instance, the word 'live' where the /e/ sound was the tricky part, and beyond expected the children could say the tricky word and create sentence like 'let's live in another place', 'I live all the time', etc. The other way was through snapping game, where teacher spreaded tricky words flashcard on the floor and children needed to snap and say the word. Moreover, the teacher also used outdoor activity, as can be seen below.

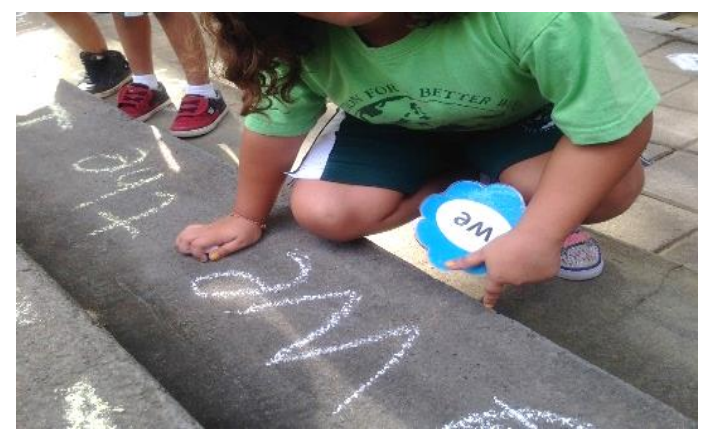


Pict. 4. Look, Copy, Write \& Say the Words

Picture 4 above shows the example of look, copy write \& say the words activity for tricky word skill. This was done outside the classroom to boost children's learning motivation. Firstly, the teacher gave 1 flashcard randomly to each child, and had them to look, copy and write the word on the ground by using chalk. Surprisingly, the children could write correctly, with neat and perfectly formed letter, even they wrote by using tool other than pencil. And then, they required to swap with another children's card and try the same steps, so they would be used to the written tricky words. Finally, all children were asked to line up and each of them needed to snap, read and say at least 3 tricky words written on the ground by using snapping tools. Therefore, through those activities, they simultaneously tried to remember, read and say their tricky words, at the same time they learned to write it correctly, which was very beneficial for them and could affect their English literacy skill.

The techniques explained in this paper were the techniques used by the teacher in teachig English literacy through Jolly Phonics. Even though the succes of the techniques could be seen through the children's performance, it should be admitted that the limitation of this study was not investigating the strategy quantitatively. Despite of the limitation, children's response and performance in learning the 5 skills in Jolly Phonics as described above indicated that they were in the middle of developing and enhancing their English literacy skill, where they knew most of letter sounds, they remember most tricky words, they were able to blend, read and at the same time write independently on their own.

\section{Closure}

English literacy skill should be introduced earlier to children as today English took the prime position in communication. Moreover, it was not an instant process to shape the children into literate individual due to the complexity of literacy itself. The 5 skills in Jolly Phonics which were delivered through variety of techniques proposed in this study has shown to be powerful ways to develop and enhance children's English literacy. For the best result, it should be carefully planned by the teacher with regard to the children's need and ability.

\section{References}

1. A. Boyadzhyan. A Systematic Approach for Teaching Phonics by Interactive Whiteboard. http://www.sierranevada.edu/assets/ABoyadzhyanfinalproject.pdf (2012)

2. A.K. Mullins. An Analysis of the Phonics Dance in a Semi-Rural Midwestern Elementary School (doctoral thesis, 2013)

3. C.M. Ekpo et al. JPS \& ESL Ppl R. Dev (presented at conference in Ibadan Uni, 2007)

4. E. Alberta. Literacy first: a plan for action (Alberta Education, Canada, 2010)

5. K. A. Roskos, J.F. Christie, D.J. Richgels. Y. Ch. 52-60 (2003)

6. L. Fakhrokhbat, D. Nejadansari. Ef. Syn. Mlt. Ph. T.L EFLYL. I. J. Rsc. Stu. In Edu. 4, 39 (2015)

7. L. Ruhaena. Pgr. Mtd. JP. thd. Bc Tls. B. Ind \& B.Ing. J. Pnlt. Hmn. 9, 192 (2008)

8. L.C. Ehri et al. Systm. Ph. Ins. Hlp. Stdnt. Lrn. R. J. Drct. Ins. 2, 121 (2001)

9. M. Morrow. Developing literacy in preschool (The Guilford Press, New York, 2007) 
10. M.I. Ogbemudia, V.M. Alasa. JPIS. Pnc. R. Dfcl. Cdhd. E. J. Ed. Rsc. Bhv. Sc. 3, 1 (2014)

11. N.N. Padmadewi. Tch. Prmt. A. L. Cl. J. Edu. Soc. Sc. 3, 45 (2016)

12.P. Dixon et al. Synthetic phonics in low-income schools in Hyderabad, India. http://jolly2.s3.amazoneaws.com/research/jph\%20research\%20Hyderabad.pdf. (2011)

13. S. Lloyd. The Phonics Handbook (Jolly Learning Ltd, England, 2010) 